\title{
Erosion of areas of oil and gas exploration along the coast of northeastern Brazil: the Guamaré hotspot
}

\author{
H. Vital ${ }^{1,2}$ \& I. M. G. Guedes ${ }^{1,3}$ \\ ${ }^{1}$ Postgraduate Program on Geodynamic and Geophysics of Geology, \\ Federal University of Rio Grande do Norte State, UFRN, Brazil \\ ${ }^{2} \mathrm{CNPq}$ Researcher \\ ${ }^{3}$ PETROBRAS S/A
}

\begin{abstract}
Guamare is one of the coastal erosion hotspots along the Brazilian coast. This area is subject to alternating erosive and depositional processes. It has extensive longshore drift to West North-West, which promotes spit growth and changes the hydrodynamic processes on the coastline. Guamare is an important area, where, since the 1980s, a series of oil and gas pipelines have been installed on Minhoto beach. Because this is a critical coastal erosion area, nowadays the pipelines are evident on the beach, although they were originally installed at a depth of $1.5 \mathrm{~m}$. A comprehensive shoreline evaluation on areas experiencing critical erosion is important for responsible hydrocarbon exploration and development. This paper describes the composition and morphological characteristics of the inner shelf adjacent to the Guamaré coastal erosion hotspot. The combination of highresolution marine seismic, satellite images, geoprocessing and bottom sediment sampling allowed the morphology correlation in the subsurface. The recognition of the pipelines' location on the bathymetric and sonographic profiles, as well as the determination of depositional and erosive areas associated with them, show the importance of this study to the environmental monitoring of submarine areas. Keywords: coastal erosion, environmental geology, continental shelf, oil and gas pipeline, NE Brazil.
\end{abstract}




\section{Introduction}

The Guamaré coastal erosion hotspot is located on the Northeast coast of Brazil, on the Potiguar Basin. It has a shoreline where oil and gas pipelines are exposed to intense erosion (fig. 1). Coastal erosion hotspots are focused zones of erosion defined as sections of coast that exhibit significantly higher rates of erosion than adjacent areas [1]. The Potiguar basin is an economically important region because of the 80 thousand oil barrels and 3 million $\mathrm{m}^{3}$ gas that it produces on a daily basis (May 2003); it is the most productive onshore oil basin in Brazil, and the second offshore [2].

The region experiences high-energy coastal and shelf-parallel currents. These are driven by combined flows as a result of oceanic, tidal and wave processes. Since strong winds are present almost all the time, water masses are well mixed without any characteristic stratification. Reworked sediments are accountable for the recent formation of different bedforms. Winds velocities measured directly on the coast reached a maximum of $9 \mathrm{~m} / \mathrm{s}$ between August and October and a minimum of $4 \mathrm{~m} / \mathrm{s}$ in April [3]. Waves measured during the Summer period near the coast around Guamaré city have an average height of 56 $\mathrm{cm}$, with a maximum height of $123 \mathrm{~cm}$, and a minimum height of $27 \mathrm{~cm}$ [4]. At the break-zone, the wave generally has a maximum height of $80 \mathrm{~cm}$ and a minimum of $22 \mathrm{~cm}$ [5]. Waves and wave-induced currents $\left(20-105 \mathrm{~cm} \cdot \mathrm{s}^{-1}\right)$ are by far the most dominant contributors to the net sediment transport along the coast of Rio Grande do Norte.

Because of the obliquity of the strongest winds, alongshore wind-driven currents increase sediment transport rates, whereas tides have a small transport capacity because of the relatively small tidal currents $\left(\approx 5-60 \mathrm{~cm} . \mathrm{s}^{-1}\right)$. The sealevel changes measured on this coast demonstrate a maximum tidal height of 3.3 $\mathrm{m}$ and $2.5 \mathrm{~m}$ respectively during spring and neap tides [6]. According to Vital [7] the RTR (Relative Tide Range) for this sector is $4<$ RTR $<15$, and so classified in the mixed wave-tide group. The general situation in this area is one of very energetic tidal conditions causing nearly continuous sediment mobility along the bottom close to the coast.

For the exploitation of the offshore gas and oil fields PETROBRAS, the Brazilian Petroleum Company, has installed a group of seven steel pipelines in this area (fig. 1), linking the offshore to the mainland facilities. These pipelines were buried at a depth of 1,5 $\mathrm{m}$ but they are now exposed on the coast and subject to erosive and deposition processes there that are influenced by hydrodynamic agents like waves, tides, and currents (fig. 2).

Many studies (e.g. [5, 8, 9]) have evaluated coastal erosion on the beach. However, no study evaluating the underwater pipelines has ever been made. Therefore, the aim of this paper is to characterize the composition and morphology of the inner shelf adjacent to the Guamarés Petroleum Pole, using bottom sediment analysis, and geophysical methods (echosounder and side scan sonar). This data is important for monitoring the area of the pipelines that are susceptible to oil spills. 


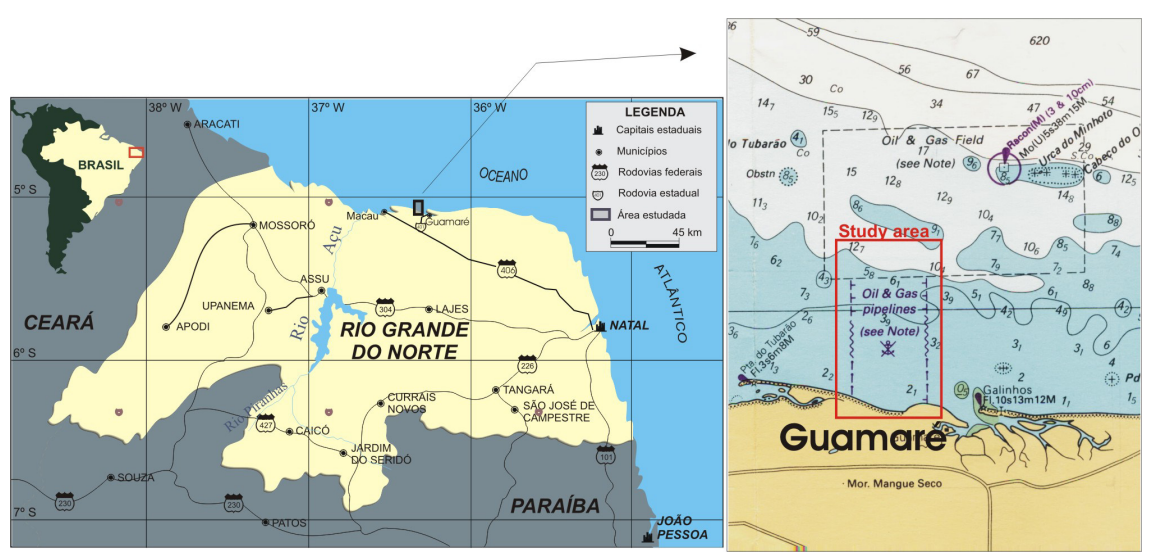

Figure 1: Location of the study area.

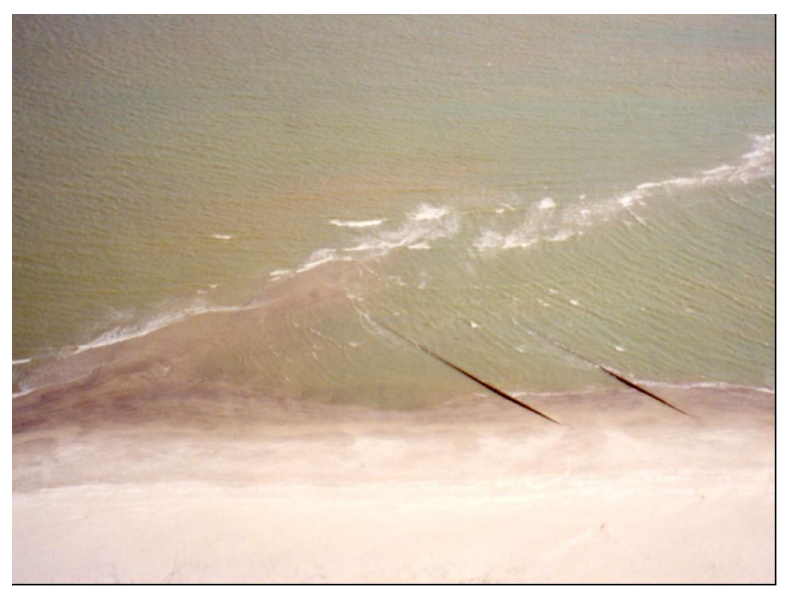

Figure 2: Pipelines exposed to erosion on the Guamaré shoreline.

\section{Methods}

Data was colleted on board fishing boats. The equipment used for hydroacoustic data was by Odom Hydrographic Systems (an echosounder and side scan sonar integrated to an internal DGPS), operating with a frequency of $200 \mathrm{kHz}$ and $0.01 \mathrm{~m}$ resolution. This sonar scans on one side only with a maximum scanning width of $80 \mathrm{~m}$. All profiles were run with a velocity of 3.5 knots, following a North-South and East-West grid with lines spaced $0.5 \mathrm{~km}$ from each other. Sediment samples were collected using a bottom-grab ("Van Veen"). Positioning for all measurements was done by DGPS, which ensured accuracy to within $10 \mathrm{~m}$. 
Sample preparation for sediment analyses involved well-known standard procedures from literature [10]. Grain-size measurements were made using a CILAS model 1180L automatic laser, particle-size ranging from 2,00 to $2 \mu \mathrm{m}$, and for the coarser fraction by dry sieving. The samples were classified by texture according to Folk and Ward [11] parameters using the SAG software developed by LAGEMAR-UFF [12] and according to sediment classification used on the Brazilian northeastern continental shelf [13].

The bathymetric data was processed with regard to tidal effect and a digital terrain model was made. This digital terrain model was overlapped by an LANDSAT 7-ETM+ image and all the data was integrated through a GIS database to correlations and interpretations.

\section{Results}

A variety of bedforms, which range from kilometers to tens of centimeters in scale are present in the study area. The larger-scale bedforms were better observed when integrating the digital terrain model with the LANDSAT 7ETM+ image (fig. 3), while the small ones were better recognized from the bathymetric profiles (fig. 4). Surface sediments were classified in seven lithofacies according to Vital et al. [13] and also integrated into the digital terrain model.

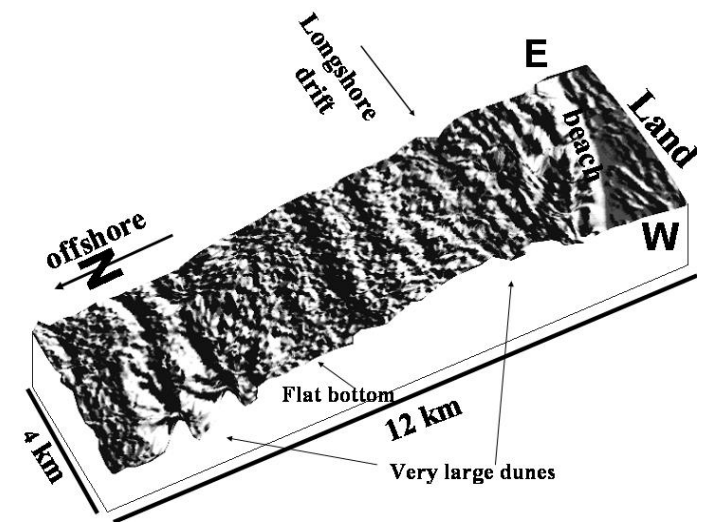

Figure 3: Digital Terrain Model integrated to the LANDSAT 7 - ETM+ Band 2. Observe areas with well-developed bedforms (very large dunes) and areas with flat morphology.

\subsection{Bedforms}

Very large subaqueous dunes occur near to and off the shore at a depth of about $10 \mathrm{~m}$. In general, the dune crests are oriented parallel to the coastline. Heights reach up to 5 meters; widths vary from $400 \mathrm{~m}$ to more than $900 \mathrm{~m}$. Echosound profiles show pronounced asymmetries with shoreward-dipping slopes nearly twice as steep as offshore dipping slopes. These bedforms are composed mainly 
of siliciclastic sediments (carbonates $<30 \%$ ). Small dunes (wave and current generated) generally superimposed the very large 3D dunes. A flat bottom is observed between the offshore and nearshore dunes. These bedforms are composed mainly of bioclastic sediments (carbonates $>70 \%$ ).

The bathymetric profiles show prominent asymmetrical dunes, which coincide with the location of the pipelines. This is as a result of longshore drift, which transports sediment from East to West, depositing sediments updrift and eroding downdrift. In this way the pipelines are acting like hard structures (fig. 3). On the side scan sonar image it is possible to visualize the pipelines underwater (fig. 5).

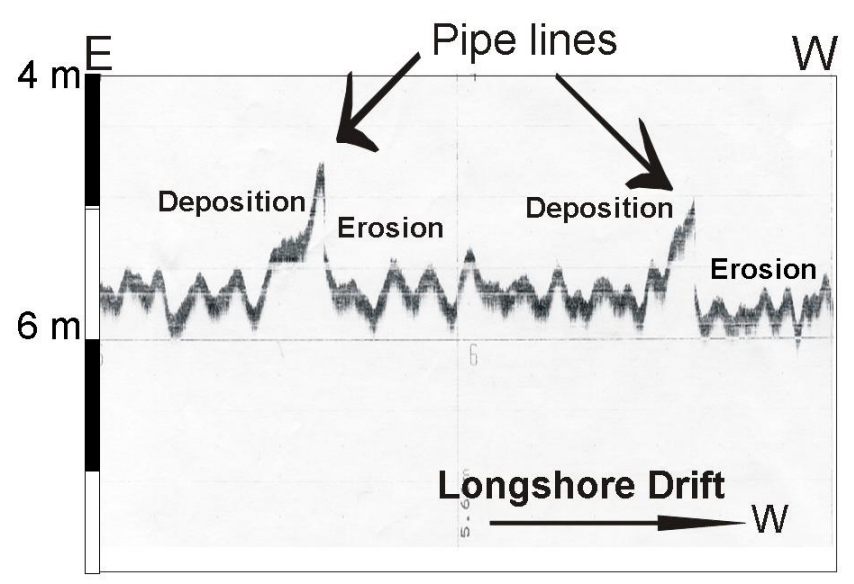

Figure 4: Part of bathymetric profile near the shoreline (5 - $6 \mathrm{~m}$ depth). Observe erosion on the downdrift side of the pipelines and deposition updrift.

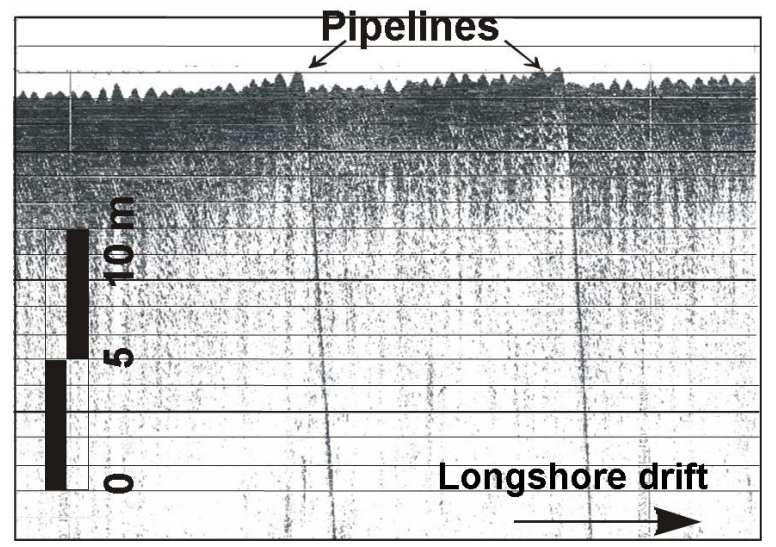

Figure 5: Part of side scan sonar profile near the shoreline (5 - $6 \mathrm{~m}$ depth) showing two pipelines exposed on the seabed. 


\subsection{Sediments, textural and compositional trends}

The surface sediment distribution for the studied area is presented in fig. 6 . Seven lithofacies were recognized: 1) Siliciclastic sands occur along the coast and offshore (about $7-8 \mathrm{~m}$ depth) where the very large 3D subaqueous dunes are well developed. The grain size varies from medium to coarse sands, moderate to poorly selected. Carbonate content is less than $30 \%$, mud content less than 2 $\mathrm{mm}$ and grains coarser than $2 \mathrm{~mm}$ are less than $15 \%$. The lithofacies cover almost $40 \%$ of this area. 2) Bioclastic gravels (carbonate content $<70 \%$, mud content $<$ $15 \%$, poorly selected), and 3) Biosiliciclastic sands with gravel and pebbles (carbonate content between 50 and $70 \%$ and mud content less than 15\%) occur between the dunes and are related to flat bottom. 4) Siliciclastic gravels, 5) Silicibioclastic gravels, 6) Silicibioclastic sands with gravel and pebbles and 7) Bioclastic sands with gravels and pebbles occur in small areas near the coast (mainly siliciclastic) or on the flat bottom (mainly bioclastic).

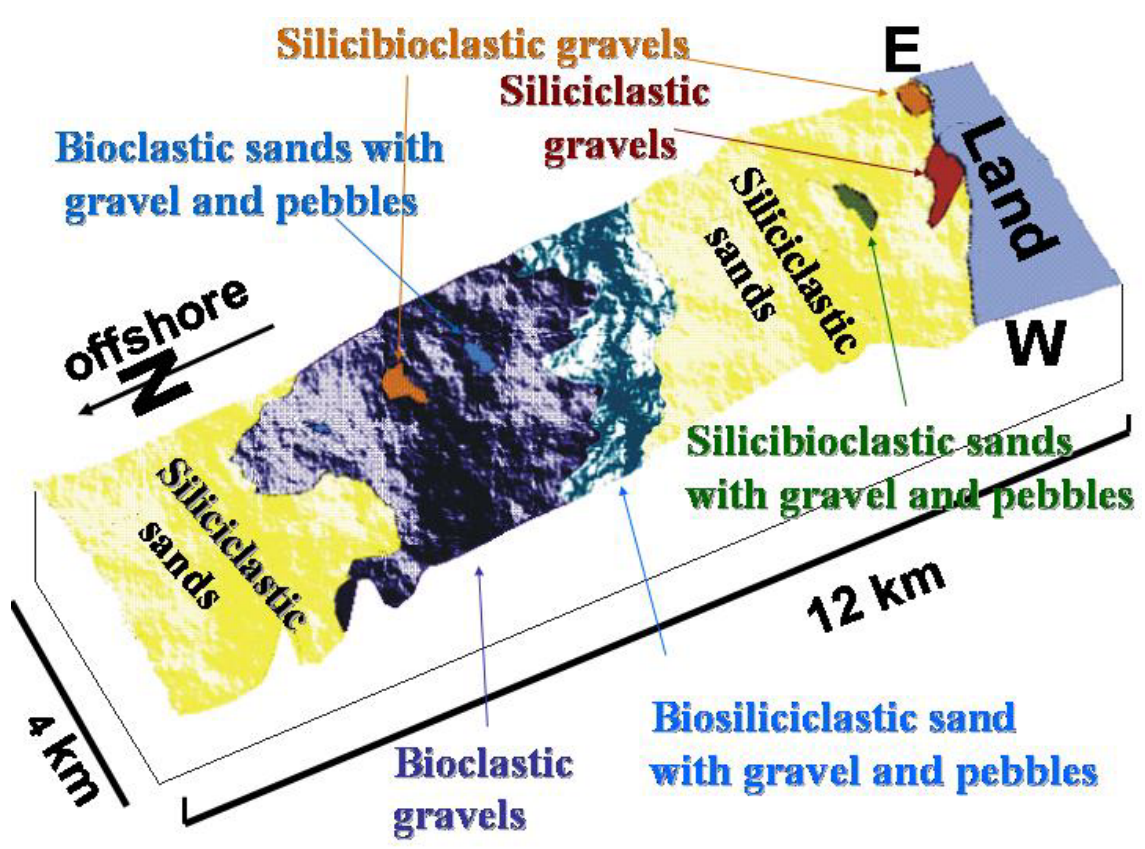

Figure 6: Distribution of surface sediments on the studied area.

\section{Conclusions}

The integration of high-resolution marine seismic, satellite images and sedimentary information allow the correlation between bedforms and surface sediments from the Brazilian continental shelf adjacent to Guamaré. A variety of 
bedforms, which range in scale from kilometers to tens of centimeters, are present on the study area. The larger-scale bedforms were better observed when integrating the digital terrain model with the LANDSAT 7-ETM+ image, while the small ones were better recognized on the bathymetric profiles. Surface sediments were classified in seven lithofacies: 1) Siliciclastic sands, 2) Bioclastic gravels, 3) Biosiliciclastic sands with gravel and pebbles, 4) Siliciclastic gravels, 5) Silicibioclastic gravels, 6) Silicibioclastic sands with gravel and pebbles and 7) Bioclastic sands with gravels and pebbles.

The recognition of exposed pipelines in the bathymetric and side scan sonar profiles allows the identification of erosional and depositional areas on the shelf induced by the presence of pipelines.

This kind of information is very important to the environmental monitoring of areas where oil is excavated.

\section{Acknowledgements}

This work was funded by the projects: PETRORISCO REDE 05/FINEP/CTPETRO), MAR-RN (FINEP/CTINFRA), PROBRAL (CAPES/DAAD 150/02) and CNPq (Proc. 500407/2004-5). The authors thank UFRN (GGEMMA/DG/PPGG) for the logistic support and ANP (Petroleum National Agency), through PRH-22 for the scholarship to the second author. Thanks are also due to GGEMMA and GEOPRO group for help during the fieldwork.

\section{References}

[1] List, J.H., Farris, A.S. \& Sullivan, C., Reversing storm hotspots on sandy beaches: spatial and temporal characteristics. Marine Ggeology, 226, pp.261-279, 2006.

[2] Soares, U.M., Rosetti, E.L. \& Cassab, C.T., Bacia Potiguar. Phoenix. Fundaçao Paleozoica Phoenix, 56, pp. 0-13, 2003.

[3] Chaves, M.S., Vital, H. \& Silveira, I.M., Beach Morphodynamic of the Serra Oil Field, northeastern Brazil. Journal of Coastal Research, SI 39 (Proccendigs of the 8th International Coastal Symposium), pg - pg. in press

[4] Frazão, E.P., Estudo hidroacustico e hidrodinâmico da plataforma continental do Rio Grande do Norte: Sistemas Açu e Potengi. Programa de Pesquisa e Pós-Graduação em Geodinâmica e Geofísica, Universidade Federal do Rio Grande do Norte, seminário de qualificação. 32p, 2005.

[5] Silveira, I.M., Vital, H., Sousa, M.E. \& Chaves, M.S., The evolutionary study of environmental conditions of the Guamaré coast (NE Brazil). Journal of Coastal Research, SI 39 (Proccendigs of the 8th International Coastal Symposium), pg - pg. in press.

[6] Araújo, M, Silva, M.A., Frazão, E.P., Vital, H., Montagne, R. \& Araujo, R. Caracterização das forçantes dinâmicas - correntes, ondas e marés - na 
região costeira de Guamaré-RN, Brasil. Relatorio Projeto Petrorisco. In press.

[7] Vital, H., The mesotidal barriers of Rio Grande do Norte. The Brazilian coastal barriers, eds. S. Dilemburg \& P. Hesp, Spring Verlag, 2006.

[8] Bandeira, J.V., Araujo, L.C. \& Valle, A.B., Emergency situation in the shoreline reach of an offshore pipeline and remedial measures. Procedings of the Coastal Engineering, 1990.

[9] Grigio, A.M.; Amaro, V.E.; Vital, H. \& Diodato, M.A., Method of analysis of the coastline evolution based in remote sensing and geographical information system products: Guamaré District Rio Grande do Norte - Northeast of Brazil. Journal of Coastal Research, SI 42, pg pg. in press.

[10] Loring, D.H. \& Rantala, R.T.T., Manual for the geochemical analysis of marine sediments and suspended particulate matter. Earth-Science Reviews. 32, pp. 235-283, 1992.

[11] Folk, R.L. \& Ward, C., Brazos river bar: A study in the insignificance of grain size parameters. Journal of Sedimentary Petrology. 27, pp.3-27, 1957.

[12] Dias, G.T.M. \& Ferraz, C.B., SAG - Sistema de Analise Granulométrica. Manual do Usuário. Pub. Interna Dept. Geologia-Lagemar/UFF www.igeo.uff.br, 2004.

[13] Vital, H., Silveira, I.M. \& Amaro, V.E., Sedimentologic chart from the Brazilian continental shelf-Guamaré to Macau (NE Brazil), based on remote sensing and geological data integration. Revista Brasileira de Geofisica. 23 in press, 2006. 